\title{
Long-Term Effects of In Vitro Growth of Mouse Oocytes on Their Maturation and Development
}

\author{
Yayoi OBATA ${ }^{1,2)}$, Yuhei MAEDA ${ }^{3)}$, Izuho HATADA ${ }^{4)}$ and Tomohiro KONO ${ }^{1,2)}$ \\ 1) Department of BioScience, Tokyo University of Agriculture, Tokyo 156-8502, ${ }^{2)}$ Bio-oriented \\ Technology Research Advancement Institution (BRAIN), Tokyo 105-0001, ${ }^{3)}$ Department of \\ Animal Science, Tokyo University of Agriculture, Kanagawa 243-0034 and ${ }^{4)}$ Biological \\ Genome Resource Center, Institute for Molecular and Cellular Regulation, Gunma University, \\ Gunma 371-8512, Japan
}

\begin{abstract}
Since very few oocytes grow completely in vivo, in vitro growth (IVG) of ovarian oocytes may provide a new source of functional oocytes. The long-term effects of in vitro maturation (IVM) of oocytes and in vitro culture of fertilized eggs have been reported; however, the effects of IVG of oocytes are unknown. Here in, we report the long-term effects of IVG of oocytes. Ovaries from 1-dayold mice containing non-growing oocytes were cultured for 10 days; the isolated follicles were then cultured for 11 days. Secondary follicles from 10-day-old mice were also cultured for 11 days. The nuclei of oocytes collected from the IVG and Graafiais follicles of adult mice were transferred to enucleated oocytes grown in vivo, respectively. Developmental competence was examined following IVM of the reconstituted oocytes. Chronologically, oocytes of 1-day-old, 10-day-old and adult mice were cultured for 22, 12 and 1 day(s). The result showed that the reconstituted eggs developed into pups at high rates after nuclear transfer and in vitro fertilization (IVF) in all the experimental groups $(29-45 \%)$. However, the pups from reconstituted eggs containing the nuclei of 22-day cultured oocytes were heavier than the control pups $(\mathrm{P}<0.05)$. We concluded that long-term culture of oocytes did not affect their nuclear ability to develop to term; however, fetal growth was affected by the culture duration or culture conditions during the initial phase of follicular growth.

Key words: Full-term development, In vitro culture, Long-term effect, Mouse, Nuclear transfer, Oocyte growth
\end{abstract}

(J. Reprod. Dev. 53: 1183-1190, 2007)

0 ocytes are the only cells that can generate embryos and produce individuals. Even in terminally differentiated cells, nuclear transfer into the ooplasm can induce reprogramming, thereby allowing the cloned embryos to acquire competence to develop to term [1]. In recent years, oocytes have been utilized for purposes such as research in the field of human reproductive medicine and studies on regenerative medicine using

Accepted for publication: July 31, 2007

Published online: September 4, 2007

Correspondence: T. Kono (e-mail: tomohiro@nodai.ac.jp) embryonic stem (ES) cells derived from cloned blastocysts [2,3]. However, only a limited number of oocytes grow completely and acquire competency because a species-specific number of follicles is selected from a large pool of primordial follicles for entry into the growth phase in vivo [4-8]. Therefore, there is an imminent critical shortage of oocytes.

Several studies endeavoring to produce competent oocytes in vitro have been reported [9-11]. Hubner et al. demonstrated that mouse ES cells, which have infinite proliferative potential, can mor- 
phologically develop into oocytes in vitro [12]. However, oocyte-like cells derived from ES cells in culture failed to arrest at metaphase in second meiosis (MII) and underwent parthenogenetic cleavage. Thus far, in vitro growth (IVG) and in vitro maturation (IVM) of primordial follicles are considered to be the most realistic models for producing competent oocytes and increasing the number of female gamete sources. Eppig et al. [13, 14], devised a 2-step culture method for production of produce oocytes from the primordial follicles of 1-day-old mice. First, the ovaries of 1-day-old mice are cultured intact for 8 days, and the obtained follicles are subsequently cultured for 14 days. These oocytes are sufficiently competent to undergo meiotic maturation, fertilization and development into live pups. We have also demonstrated successful development of pups from oocytes that were differentiated from the pre-meiotic female germ cells of mouse foetuses at 12.5 days post coitum (dpc) using a nuclear transfer technique combined with Eppig's 2-step culture method [15]. In this strategy, to overcome the cytoplasmic deficiency of IVG oocytes, the nuclei of oocytes that were differentiated after ovarian culture for 17 days and follicular culture for 11 days were transferred into ooplasm grown and matured in vivo. The key factor in this method is the provision of a large number of maternal genomes.

On the other hand, it has been suggested that in vitro culture of ruminant embryos causes a high frequency of multiple abnormalities, which are collectively referred to the large offspring syndrome $[16,17]$. Several studies have reported that assisted reproductive technology (ART) is associated with an increased risk of low-birth-weight infants and birth defects in humans [18-20]. The issue regarding whether the abnormalities are associated with the duration of culture and the degree of complications encountered while manipulating the gametes is of particular interest.

In the present study, in order to investigate whether the period of in vitro culture during oocyte growth affects post-implantation and post-natal development, the following series of experiments were performed: (1) oocytes at various stages derived from 1-day-old, 10-day-old and adult mice were cultured for 22, 12 and 1 days, respectively; (2) the nuclei of oocytes cultured in vitro were transferred into ooplasm grown and matured in vivo; (3) the reconstituted M II oocytes were subjected to in vitro fertilization (IVF); and (4) the blastocysts obtained after 4-day in vitro culture were transferred to pseudopregnant female mice.

\section{Materials and Methods}

\section{Animals}

All procedures described in this study were reviewed and approved by the Tokyo University of Agriculture Institutional Animal Care and Use Committee and were performed in accordance with the Guidelines for Proper Conduct of Animal Experiments as promulgated by the Science Council of Japan. BDF1 (C57BL/6N $\times$ DBA /2; Clea Japan, Tokyo, Japan) hybrid mice were used for all the experiments.

\section{IVG of non-growing oocytes from newborn mice (Experiment 1)}

The viability, growth, and maturation of oocytes after in vitro culture were assessed using alpha minimum essential medium (alpha-MEM; Invitrogen, Carlsbad, CA, USA) supplemented with $50 \mathrm{mg} / 1$ streptomycin sulphate and $75 \mathrm{mg} / 1$ penicillin G. Ovaries obtained from 1-day-old mice were cultured in medium containing $10 \%$ fetal bovine serum (FBS) on Coaster Transwell polycarbonate membranes (3.0 $\mu \mathrm{m}$ pore size, $24 \mathrm{~mm}$ diameter; Corning, Lowell, MA, USA) in 5\% $\mathrm{CO}_{2}$ and $95 \%$ air at $37 \mathrm{C}$ [13]. Approximately $1.5 \mathrm{ml}$ of the medium was dispensed in the compartment, and $0.7-0.8 \mathrm{ml}$ of the medium was added to the surface of the membrane. A total of 6 ovaries were placed on each membrane. On day 10 , secondary follicles were mechanically isolated from the ovaries and cultured for 11 days in medium containing 5\% FBS, $0.1 \mathrm{IU} / \mathrm{ml}$ follicle-stimulating hormone $(\mathrm{FSH}$; Sigma-Aldrich, St. Louis, MO, USA), $5 \mu \mathrm{g} / \mathrm{ml}$ insulin, $5 \mu \mathrm{g} / \mathrm{ml}$ transferrin and $5 \mathrm{ng} / \mathrm{ml}$ selenium (ITS; Roche, Basel, Switzerland) on Coaster TranswellCOL membranes $(3.0 \mu \mathrm{m}$ pore size, $12 \mathrm{~mm}$ diameter; Corning) in $5 \% \mathrm{CO}_{2}$ and $95 \%$ air at $37 \mathrm{C}$. Approximately $1.5 \mathrm{ml}$ of the medium was dispensed in the compartment, and $0.5 \mathrm{ml}$ of the medium was added to the surface of the membrane. Half of the culture media was replaced every 3 days. An interference microscope $(200 \times$ magnification; Nikon, Tokyo, Japan) and a eyepiece micrometer $(10 \times \mathrm{A}$; Nikon) were used to measure the diameters of the oocytes grown in vitro (Fig.1). 
Experiment 1
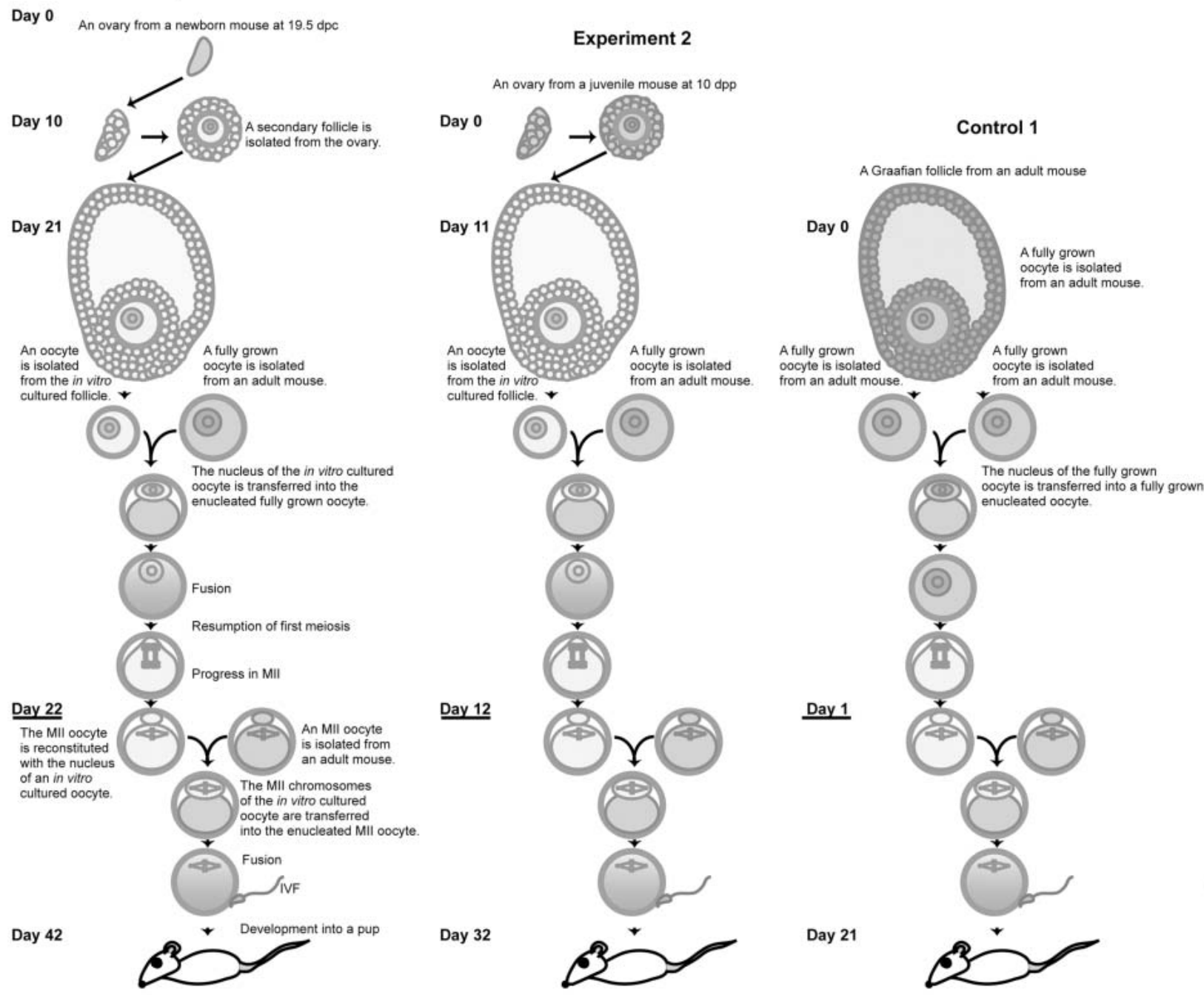

Fig. 1. Schematic diagram illustrating the experimental design and production of functional oocytes from immature oocytes. In vivo and in vitro derivatives are pink and yellow, respectively. With regard to the donor oocytes, primordial (experiment 1), secondary (experiment 2) and Graafian's follicles (control 1) were cultured for 21, 11 and 0 days, respectively, in order to attain the same chronological age. Serial nuclear transfer to cytoplasm grown and matured in vivo was conducted at the GV and MII stages, respectively. Following IVF, the resultant blastocysts were transferred to pseudopregnant females, and the long-term effects were assessed.

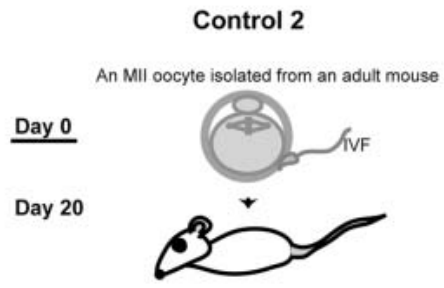

IVG of growing oocytes from 10-day-old mice (Experiment 2)

Secondary follicles isolated from the ovaries of 10-day-old mice were cultured as mentioned above. In short, secondary follicles were mechanically isolated and cultured for 11 days in medium containing 5\% FBS, $0.1 \mathrm{IU} / \mathrm{ml} \mathrm{FSH}$ and ITS on Coaster Transwell-COL membranes. Approximately $1.5 \mathrm{ml}$ of the medium was dispensed in the compartment, and $0.5 \mathrm{ml}$ of the medium was added to the surface of the membrane (Fig.1). 
Table 1. Development of oocytes after IVG

\begin{tabular}{|c|c|c|c|c|c|c|c|}
\hline & \multirow{2}{*}{$\begin{array}{l}\text { Culture } \\
\text { duration }\end{array}$} & \multicolumn{4}{|c|}{ No. of oocytes } & \multicolumn{2}{|c|}{$\begin{array}{l}\text { No. of embryos } \\
\text { developed to }\end{array}$} \\
\hline & & cultured & $\begin{array}{l}\text { undergone } \\
\text { GVBD }\end{array}$ & $\begin{array}{l}\text { matured } \\
\text { into MII }\end{array}$ & $\begin{array}{l}\text { normally } \\
\text { fertilized }\end{array}$ & 2-cell & blastocyst \\
\hline $\begin{array}{l}\text { Primodial follicles of } \\
\text { 1-day-old mice }\end{array}$ & 22 days & 91 & $\begin{array}{c}52^{\mathrm{a}} \\
(57 \%)\end{array}$ & $\begin{array}{c}19^{\mathrm{a}} \\
(21 \%)\end{array}$ & $\begin{array}{c}1^{\mathrm{a}} \\
(5 \%)\end{array}$ & $\begin{array}{c}0 \\
(0 \%)\end{array}$ & $\begin{array}{c}0 \\
(0 \%)\end{array}$ \\
\hline $\begin{array}{l}\text { Secondary follicles of } \\
\text { 10-day-old mice }\end{array}$ & 12 days & 140 & $\begin{array}{l}105^{\mathrm{b}} \\
(75 \%)\end{array}$ & $\begin{array}{c}51^{\mathrm{c}} \\
(36 \%)\end{array}$ & $\begin{array}{c}19^{\mathrm{b}} \\
\left(37^{\circ}\right)\end{array}$ & $\begin{array}{c}8 \\
(42 \%)\end{array}$ & $\begin{array}{c}0 \\
(0 \%)\end{array}$ \\
\hline
\end{tabular}

a vs. b: $\mathrm{P}<0.01$. a vs. c: $\mathrm{P}<0.05$.

\section{Nuclear transfer and IVM}

Adult female mice were injected with 5 IU equine chorionic gonadotropin (eCG) (Serotropin ${ }^{\circledR}$; Teikoku Zoki, Tokyo, Japan), and 5 IU human chorionic gonadotropin (hCG) (Puberogen ${ }^{\circledR}$; Sankyo Zoki, Tokyo, Japan) was injected $48 \mathrm{~h}$ after the eCG injection. Freshly ovulated MII oocytes were collected from the oviducts 14-16 h after the hCG injection. Fully grown oocytes were collected at the germinal vesicle $(\mathrm{GV})$ stage from the ovaries $44-48$ $\mathrm{h}$ after the eCG injection.

Serial nuclear transfers were performed as described previously $[15,21]$. In order to prevent GV breakdown, the GV-stage oocytes were manipulated in M2 medium containing $240 \mu \mathrm{M}$ dibutyryl cAMP (Sigma). Karyoplasts obtained from the oocytes, which were cultured for 21 days (Experiment 1) and for 11 days (Experiment 2), were fused with enucleated fully grown GV-stage oocytes using the inactivated Sendai virus (2700 hemagglutinating activity units $/ \mathrm{ml}$ ). As a control, karyoplasts obtained from fully grown GV-stage oocytes were fused with enucleated fully grown GV-stage oocytes using the inactivated Sendai virus (control 1). The reconstituted oocytes were cultured in alpha-MEM containing 5\% FBS in 5\% $\mathrm{CO}_{2}, 5 \% \mathrm{O}_{2}$ and $90 \% \mathrm{~N}_{2}$ at $37 \mathrm{C}$. After $14 \mathrm{~h}$, the MII chromosomes were transferred from the reconstituted oocytes to the enucleated and ovulated MIIstage oocytes in order to yield cytoplasmic competency (Fig. 1).

\section{IVF, in vitro culture and embryo transfer}

Sperm were collected from fertile mice, and the reconstituted oocytes were incubated with capacitated sperm for $3 \mathrm{~h}$ in T6 medium. After IVF, reconstituted embryos containing single male and female pronuclei were regarded as normally fertil- ized eggs and were cultured at $37 \mathrm{C}$ for 4 days in M16 medium in $5 \% \mathrm{CO}_{2}, 5 \% \mathrm{O}_{2}$ and $90 \% \mathrm{~N}_{2}$. The resulting blastocysts were transferred to the uterine horns of pseudopregnant female mice at $2.5 \mathrm{dpc}$. As a control, freshly ovulated oocytes (control 2) were subjected to the same sequence of IVF, in vitro culture and embryo transfer as that performed for the reconstituted oocytes. The ability of these blastocysts to develop into pups was analysed at 19.5 dpc by performing a caesarean section (Fig. 1). All the experiments described above were repeated at least three times.

\section{Statistical analysis}

Data on the growth of the oocytes and weight of the pups were examined using the Student's $t$-test. The rate of follicular viability, oocyte maturation and embryonic development were analyzed using the chi-square test.

\section{Results}

\section{Growth of oocytes cultured in alpha-MEM medium}

When the ovaries of 1-day-old mice were cultured for 10 days, the size (mean \pm SD) of the oocytes enclosed within the secondary follicles was $51.7 \pm 3.86 \mu \mathrm{m}(\mathrm{n}=179)$. Subsequently, the secondary follicles were cultured for 11 days. On day 21, $69 \%$ of the oocytes were enclosed within the follicles; they were now $68.6 \pm 3.87 \mu \mathrm{m}(\mathrm{n}=124)$ in size. These oocytes underwent the first meiotic division $(19 / 91)$ but were not successful with regard to IVF $(1 / 19)$. The mean diameter of the oocytes enclosed within intact secondary follicles isolated from the 10 -day-old mice was $53.8 \pm 3.91 \mu \mathrm{m}(\mathrm{n}=250)$. Some of the oocytes ovulated by 11 days after follicular culture and $56 \%$ of the oocytes were enclosed 
Table 2. Development of oocytes reconstituted with nuclei from oocytes after IVG and IVM

\begin{tabular}{|c|c|c|c|c|c|c|c|c|c|}
\hline & \multirow[b]{2}{*}{$\begin{array}{l}\text { Culture } \\
\text { duration }\end{array}$} & \multicolumn{5}{|c|}{ No. of oocytes } & \multicolumn{2}{|c|}{ No. of embryos } & \multirow{2}{*}{$\begin{array}{l}\text { No. of } \\
\text { living } \\
\text { pups }\end{array}$} \\
\hline & & $\overline{N T}$ & fused & $\begin{array}{l}\text { matured } \\
\text { into MII }\end{array}$ & NT & fused & $\begin{array}{l}\text { normally } \\
\text { fertilized }\end{array}$ & $\begin{array}{c}\text { developed to } \\
\text { blastocyst }\end{array}$ & \\
\hline $\begin{array}{l}\text { Primodial follicles of } \\
\text { 1-day-old mice } \\
\text { (Experiment 1) }\end{array}$ & 22 days & 133 & $\begin{array}{c}94 \\
(71 \%)\end{array}$ & $\begin{array}{c}89 \\
(95 \%)\end{array}$ & 79 & $\begin{array}{c}66 \\
(84 \%)\end{array}$ & $\begin{array}{c}49 \\
(74 \%)\end{array}$ & $\begin{array}{c}47 \\
(96 \%)\end{array}$ & $\begin{array}{c}14 \\
(29 \%)\end{array}$ \\
\hline $\begin{array}{l}\text { Secondary follicles of } \\
\text { 10-day-old mice } \\
\text { (Experiment 2) }\end{array}$ & 12 days & 187 & $\begin{array}{c}168 \\
(90 \%)\end{array}$ & $\begin{array}{c}138 \\
(82 \%)\end{array}$ & 121 & $\begin{array}{c}106 \\
(88 \%)\end{array}$ & $\begin{array}{c}84 \\
(79 \%)\end{array}$ & $\begin{array}{c}77 \\
(92 \%)\end{array}$ & $\begin{array}{c}25 \\
(30 \%)\end{array}$ \\
\hline $\begin{array}{l}\text { Graafian's follicles of } \\
\text { adult mice } \\
\text { (Control 1) }\end{array}$ & 1 day & 114 & $\begin{array}{c}95 \\
(83 \%)\end{array}$ & $\begin{array}{c}90 \\
(95 \%)\end{array}$ & 86 & $\begin{array}{c}73 \\
(85 \%)\end{array}$ & $\begin{array}{c}55 \\
(75 \%)\end{array}$ & $\begin{array}{c}52 \\
(95 \%)\end{array}$ & $\begin{array}{c}25 \\
(45 \%)\end{array}$ \\
\hline $\begin{array}{l}\text { M II oocytes of } \\
\text { adult mice } \\
\text { (Control 2) }\end{array}$ & 0 day & - & - & - & - & - & $\begin{array}{c}40 \\
(89 \%)\end{array}$ & $\begin{array}{c}39 \\
(98 \%)\end{array}$ & $\begin{array}{c}31 \\
(79 \%)\end{array}$ \\
\hline
\end{tabular}

NT: nuclear transferred.

within follicles. They had reached $69.2 \pm 3.57 \mu \mathrm{m}$ $(n=140)$ in size, and had undergone the first meiotic division (51/140). After IVF, 19 eggs extruded a second polar body and formed two pronuclei. No significant differences were observed in the sizes of oocytes of the same chronological age that were cultured for 21 and 11 days. However, the maturation and fertilization rates of the oocytes cultured for 11 days were significantly higher than for those cultured for 21 days $(\mathrm{P}<0.05)$. In both cases, the resultant eggs after IVF did not develop beyond the 4-cell stage (Table 1).

Post-implantation development of reconstituted eggs containing the nuclei of oocytes produced in vitro

We initially we observed that physically denuded oocytes at the GV stage had high potential to mature to the MII stage $(487 / 528 ; 92 \%)$ similar to cumulus enclosed oocytes (291/307; 95\%); however, denuded oocytes had poor ability to achieve fertilization $(1 / 152 ; 0.6 \%)$ and pre-implantation development $(0 / 1)$. When zonae pellucidae of denuded oocytes were cut, the fertilization rate improved $(71 / 135 ; 52.6 \%)$ but the ability to develop to the blastocyst stage was quite low $(3 / 70 ; 4 \%)$. These results and Table 1 indicate that IVG and IVM of oocytes and denudation of cumulus cells caused zona hardening and critical cytoplasmic deficiency. Therefore, we conducted serial nuclear transfer experiments to analyze the nuclear competence of oocytes grown and matured in vitro and to investigate whether the duration of culture affects post-implantation development (Fig. 1).
In order to attain the same chronological age for the donor oocytes, primordial (experiment 1), secondary (experiment 2) and Graafian follicles (control 1) were cultured for 21, 11 and 0 days, respectively (Fig. 1). After nuclear transfer, oocytes reconstituted with the nuclei of the oocytes cultured for 21, 11 and 0 days were highly competent to mature into MII-stage oocytes (95, 82 and 95\%, respectively) and develop into blastocysts (96, 92 and $95 \%$, respectively; Table 2 ). In the post-implantation stage, the competency of the reconstituted oocytes was unaffected by the duration of culture. When the maternal nuclei were donated from oocytes cultured for 22 or 12 days, approximately $30 \%$ of the reconstituted eggs developed into pups (14/49 and 25/84, respectively). This observation was made with regard to the developmental rate of the reconstituted eggs containing nuclei obtained from oocytes cultured for 1 day (control 1, 45\%; Table 2).

\section{Offspring from oocytes produced in vitro}

No obvious abnormalities were observed in any of the pups or placentae. The pups $(1.48 \pm 0.17 \mathrm{~g}$, mean \pm SD) and placentae (135 $\pm 35 \mathrm{mg})$ from the reconstituted eggs, which contained the nuclei of oocytes cultured for 22 days after their isolation from 1-day-old mice, were heavier than those of control 2 (pups, $1.25 \pm 0.14$ g; placentae, $89 \pm 23 \mathrm{mg}$ ). In the other experimental group, no significant difference was observed between the weight of the pups and placentae and those of the pups and placentae of control 2 (Fig. 2). In the present 
(a)

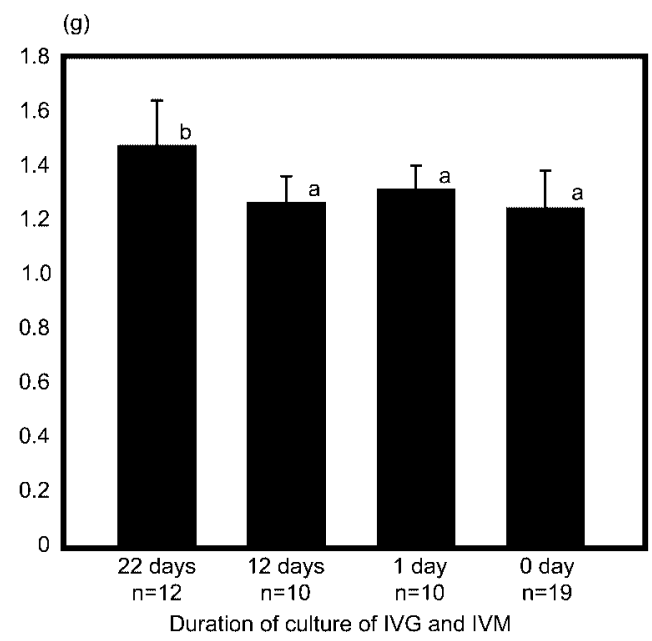

(b)

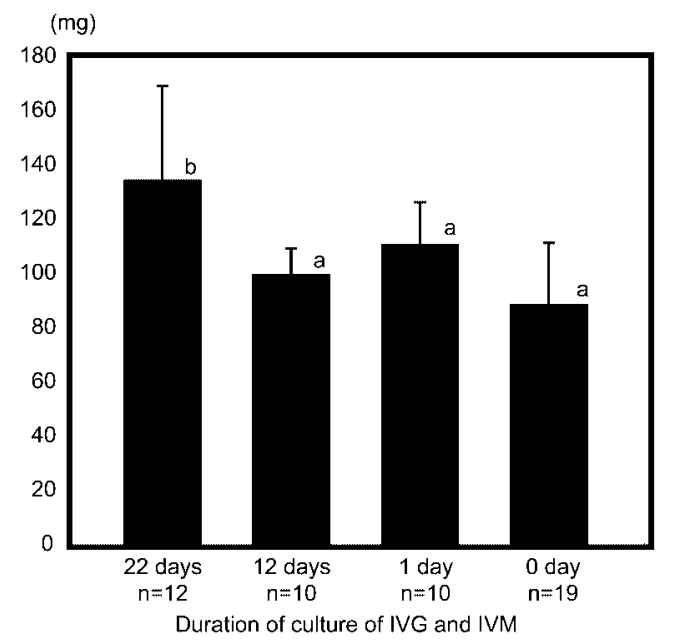

Fig. 2. Weight of the pups (a) and placentae (b) derived from reconstituted oocytes at birth. The bars indicate the mean weights and SDs of the pups (A) and placentae (B) obtained from the reconstituted eggs, which contained the nuclei of oocytes cultured for 22 (experiment 1), 12 (experiment 2$), 1$ (control 1 ) and 0 (control 2) day(s) after isolation from 1-day-old, 10day-old, adult and superovulated adult mice, respectively. A significant difference was only observed in the weights of the pups and placentae that contained the nuclei of oocytes cultured for 22 days compared with those of the pups and placentae in control 2. a vs. b: $\mathrm{P}<0.05$.

experimental series, only 1 pup died at birth (1/64, $1.6 \%$ ), and all the tested pups were fertile. The lifespan of the obtained pups was 818 days (experi- ment $1 ; \mathrm{n}=4), 765$ days (experiment $2 ; \mathrm{n}=3$ ), 720 days (control 1; $\mathrm{n}=3$ ) and 810 days (control 2; $\mathrm{n}=4$ ); this appeared to be normal despite the long culture period of the donated oocytes.

\section{Discussion}

In the present study, we analyzed whether the duration of culture affects pre- and post-implantation and post-natal development. No significant difference was observed between the size of the oocytes obtained from 1-day-old mice and cultured for a total of 21 days and those obtained from 10day-old mice and cultured for 11 days. However, the maturation rate of the oocytes cultured for 11 days was significantly higher than that of oocytes cultured for 21 days $(\mathrm{P}<0.05)$. The same tendency was observed in the fertilization rate. There are several possibilities to explain the incompetency of the oocytes cultured for 21 days. Formation and maintenance of gap junctional communication, which is mediated by factors such as Connexin 37 [22] and kit ligand [23], between granulosa cells and the oocytes during the initial phase of follicular growth may be insufficient under these culture conditions. Furthermore, zona hardening might occur more severely or the zona structure might be defective in the oocytes cultured for 21 days. Since replacement of the cytoplasm and zona pellucida by nuclear transfer in both cases led to a high rate of successful maturation and fertilization, it is plausible that long-term IVG or in vitro culture during the initial phase of follicular growth induced these deficiencies. No significant differences were observed with regard to the rate at which the eggs reconstituted with the nuclei of the oocytes cultured for 22, 12 and 1 days developed into blastocysts and pups (Table 2). In contrast to use of complicated manipulation, application of the nuclear transfer technique may prevent critical long-term effects. However, a significant increase in weight was observed in oocytes from the primordial follicles of 1-day-old mice that were cultured in vitro for 22 days (Fig. 2). The overgrowth phenotype at birth exhibits many common features in ruminants and is caused by IVM and IVF [16, 17]. The expression of $I g f 2 r$, which is an imprinted gene that negatively regulates fetal growth, is decreased in the large offspring of sheep due to abnormal demethylation of $I g f 2 r$ [24]. The Igf $2 r$ gene is meth- 
ylated in the early phase of oogenesis [25]. However, we previously reported the absence of abnormal methylation of the Igf2r gene in oocytes cultured for 28 days and the pups from these oocytes [15]. Although the precise mechanisms of overgrowth are not understood, the culture duration of oocytes or culture conditions during the initial phase of follicular growth might induce epimutations in some genes.

In this study, we used a nuclear transfer technique to successfully produce a high rate of live offspring $(29 \%)$ from embryos that contained the nuclei of oocytes cultured for 22 days after isolation from 1-day-old mice. Many features are essential for formation of a functional oocyte; these include meiotic maturation, cytoplasmic maturation and the establishment of genomic imprinting [21, 26, 27]. In mice, oocyte-specific imprinting is naturally established during oocyte growth up to $60-65 \mu \mathrm{m}$ in diameter $[25,28]$. Therefore, even when the donor oocytes did not grow to their maximum size, as long as they attained a diameter of $\geq-60 \mu \mathrm{m}$ after IVG, our strategy produced functional oocytes. This is potentially applicable for preservation and increase of the number of wild animals, valuable livestock and transgenic/knockout animals. On the other hand, in the UK, USA, France and Australia, it has been reported that the frequency at which ART children are born with Beckwith-Wiedemann syndrome (BWS) is 4- to 15-fold higher than the population risk or that of non-ART children. In ART children with Angelman syndrome, the loss of methylation in the Snrpn gene is observed at a 6fold higher frequency [29]. Analyses of a large number of IVG oocytes and pups from IVG oocytes in mice can help to elucidate the cause of epimutation and help to establish safe ART.

In conclusion, we demonstrated that (1) oocytes from the primordial follicles of 1-day-old mice and secondary follicles of 10-day-old mice acquired competence to develop into pups at a high rate (29\% and $30 \%$, respectively) after IVG, nuclear transfer, IVF and embryo transfer and that (2) the long-term culture of oocytes did not affect their nuclear ability to develop to term; however, fetal growth was affected by the duration of culture or culture conditions during the initial phase of follicular growth.

\section{Acknowledgment}

This study was supported by grants from the Ministry of Education, Culture, Sports, Science and Technology of Japan to Y.O. and the Bio-oriented Technology Research Advancement Institution (BRAIN), Japan, to T.K.

\section{References}

1. Campbell KH, McWhir J, Ritchie WA, Wilmut I. Sheep cloned by nuclear transfer from a cultured cell line. Nature 1996; 380: 64-66.

2. Munsie MJ, Michalska AE, $\mathrm{O}^{\prime}$ Brien CM, Trounson AO, Pera MF, Mountford PS. Isolation of pluripotent embryonic stem cells from reprogrammed adult mouse somatic cell nuclei. Curr Biol 2000; 10: 989992.

3. Wakayama T, Tabar V, Rodriguez I, Perry AC, Studer L, Mombaerts P. Differentiation of embryonic stem cell lines generated from adult somatic cells by nuclear transfer. Science 2001; 292: 740-743.

4. Baker T. In: Balin H, Glasser S (eds.), Reproductive Biology. Amsterdam: Excerpta Medica; 1972: 398437.

5. Byskov AG. In: Austin CR, Short RV (eds.), Germ Cells and Fertilization. Cambridge: Cambridge University Press; 1982: 1-16.

6. Krarup T, Pedersen T, Faber M. Regulation of oocyte growth in the mouse ovary. Nature 1969; 224:
187-188.

7. Peters $\mathbf{H}$. The development of the mouse ovary from birth to maturity. Acta Endocrinol (Copenh) 1969; 62: 98-116.

8. Peters H, Levy E. Cell dynamics of the ovarian cycle. J Reprod Fertil 1966; 11: 227-236.

9. Lenie S, Cortvrindt R, Adriaenssens T, Smitz J. A reproducible two-step culture system for isolated primary mouse ovarian follicles as single functional units. Biol Reprod 2004; 71: 1730-1738.

10. Yamamoto K, Otoi T, Koyama N, Horikita N, Tachikawa S, Miyano T. Development to live young from bovine small oocytes after growth, maturation and fertilization in vitro. Theriogenology 1999; 52: 81-89.

11. Dyce PW, Wen L, Li J. In vitro germline potential of stem cells derived from fetal porcine skin. Nat Cell Biol 2006; 8: 384-390.

12. Hubner K, Fuhrmann G, Christenson LK, Kehler J, Reinbold R, De La Fuente R, Wood J, Strauss JF, 
3rd, Boiani M, Scholer HR. Derivation of oocytes from mouse embryonic stem cells. Science 2003; 300: 1251-1256.

13. Eppig JJ, O'Brien MJ. Development in vitro of mouse oocytes from primordial follicles. Biol Reprod 1996; 54: 197-207.

14. O'Brien MJ, Pendola JK, Eppig JJ. A revised protocol for in vitro development of mouse oocytes from primordial follicles dramatically improves their developmental competence. Biol Reprod 2003; 68: 1682-1686.

15. Obata Y, Kono T, Hatada I. Gene silencing: maturation of mouse fetal germ cells in vitro. Nature 2002; 418: 497.

16. Walker SK, Hartwich KM, Seamark RF. The production of unusually large offspring following embryo manipulation: concepts and challenges. Theriogenology 1996; 45: 111-120.

17. Young LE, Butterwith SC, Wilmut I. Increased ovine fetal weight following transient asynchronous embryo transfer is not associated with increased placental weight at day 21 of gestation. Theriogenology 1996; 45: 231.

18. Doyle P, Beral V, Maconochie N. Preterm delivery, low birthweight and small-for-gestational-age in liveborn singleton babies resulting from in vitro fertilization. Hum Reprod 1992; 7: 425-428.

19. Maher ER. Imprinting and assisted reproductive technology. Hum Mol Genet 2005; 14 Spec No 1: R133-138.

20. McDonald SD, Murphy K, Beyene J, Ohlsson A. Perinatel outcomes of singleton pregnancies achieved by in vitro fertilization: a systematic review and meta-analysis. J Obstet Gynaecol Can 2005; 27:
449-459.

21. Bao S, Obata Y, Carroll J, Domeki I, Kono T. Epigenetic modifications necessary for normal development are established during oocyte growth in mice. Biol Reprod 2000; 62: 616-621.

22. Simon AM, Goodenough DA, Li E, Paul DL. Female infertility in mice lacking connexin 37. Nature 1997; 385: 525-529.

23. Driancourt MA, Reynaud K, Cortvrindt R, Smitz J. Roles of KIT and KIT LIGAND in ovarian function. Rev Reprod 2000; 5: 143-152.

24. Young LE, Fernandes $K$, McEvoy TG, Butterwith SC, Gutierrez CG, Carolan C, Broadbent PJ, Robinson JJ, Wilmut I, Sinclair KD. Epigenetic change in IGF2R is associated with fetal overgrowth after sheep embryo culture. Nat Genet 2001; 27: 153-154.

25. Hiura H, Obata Y, Komiyama J, Shirai M, Kono T. Oocyte growth-dependent progression of maternal imprinting in mice. Genes Cells 2006; 11: 353-361.

26. Bao S, Obata Y, Ono Y, Futatsumata N, Niimura S, Kono T. Nuclear competence for maturation and pronuclear formation in mouse oocytes. Hum Reprod 2002; 17: 1311-1316.

27. Sorensen RA, Wassarman PM. Relationship between growth and meiotic maturation of the mouse oocyte. Dev Biol 1976; 50: 531-536.

28. Obata Y, Kono T. Maternal primary imprinting is established at a specific time for each gene throughout oocyte growth. J Biol Chem 2002; 277: 5285-5289.

29. Cox GF, Burger J, Lip V, Mau UA, Sperling K, Wu BL, Horsthemke B. Intracytoplasmic sperm injection may increase the risk of imprinting defects. $A m$ J Hum Genet 2002; 71: 162-164. 